\title{
Three New Species of Free-living Marine Nematodes (Nematoda: Enoplida) from Northern Japan
}

\author{
Daisuke Shimada $^{1}$, Hiroshi Kajihara ${ }^{2}$ and Shunsuke F. Mawatari ${ }^{2}$ \\ ${ }^{1}$ Department of Natural History Sciences, Graduate School of Science, Hokkaido University, \\ Sapporo, 060-0810 Japan \\ E-mail:d-shimada@mail.sci.hokudai.ac.jp \\ ${ }^{2}$ Department of Natural History Sciences, Faculty of Science, Hokkaido University, \\ Sapporo, 060-0810 Japan \\ E-mail:kazi@mail.sci.hokudai.ac.jp(HK); shunfm@sci.hokudai.ac.jp (SFM)
}

(Received 14 September 2008; Accepted 30 April 2009)

\begin{abstract}
Three new species of free-living marine nematodes, belonging to three genera, Epacanthion Wieser, 1953, Enoplolaimus De Man, 1893 (both family Enoplidae Dujardin, 1845), and Oncholaimus Dujardin, 1845 (family Oncholaimidae Filipjev, 1916), are described from northern Japan. Epacanthion quadridiscus sp. nov. is most similar to Epacanthion enoploidiforme (Gerlach, 1953), E. gorgonocephalum Warwick, 1970, and E. georgei Inglis, 1971 in spicule length and the absence of a precloacal supplement, but differs from them in the shape of the gubernaculum and the arrangement of the subcephalic and cervical setae in the male. Enoplolaimus longigubernaculum $\mathrm{sp}$. nov. differs from all of its congeners in having a long and straight gubernaculum. Oncholaimus secundicollis sp. nov. is distinguished from all of its congeners by the presence of a precloacal papilla, postcloacal papilla, and tail papilla in the male.
\end{abstract}

Key Words: Nematoda, Enoplida, Epacanthion, Enoplolaimus, Oncholaimus, new species, Japan.

\section{Introduction}

Since the first description of four species of free-living marine nematodes from Japanese waters by Steiner and Hoeppli (1926), 71 species have been described from this area (Allgén 1951; Wieser 1955; Kito 1976, 1977, 1978a, b, 1981; Allen and Noffsinger 1978; Yoshimura 1980a, b, 1982; Aryuthaka 1989a, b; Kito and Hope 1999). Of these, 19 are classified in the Enoplida, while the rest belong to either the Chromadorida or the Monhysterida.

During the course of a faunal survey of free-living marine nematodes in 2007, many specimens belonging to the Enoplida were obtained from intertidal sandy sediments around Hokkaido, northern Japan (Fig. 1A). As a result of our taxonomic study of the material, we here present the descriptions of three new species of the genera Epacanthion Wieser, 1953, Enoplolaimus De Man, 1893 (family Enoplidae Dujardin, 1845), and Oncholaimus Dujardin, 1845 (family Oncholaimidae Filipjev, 1916). 


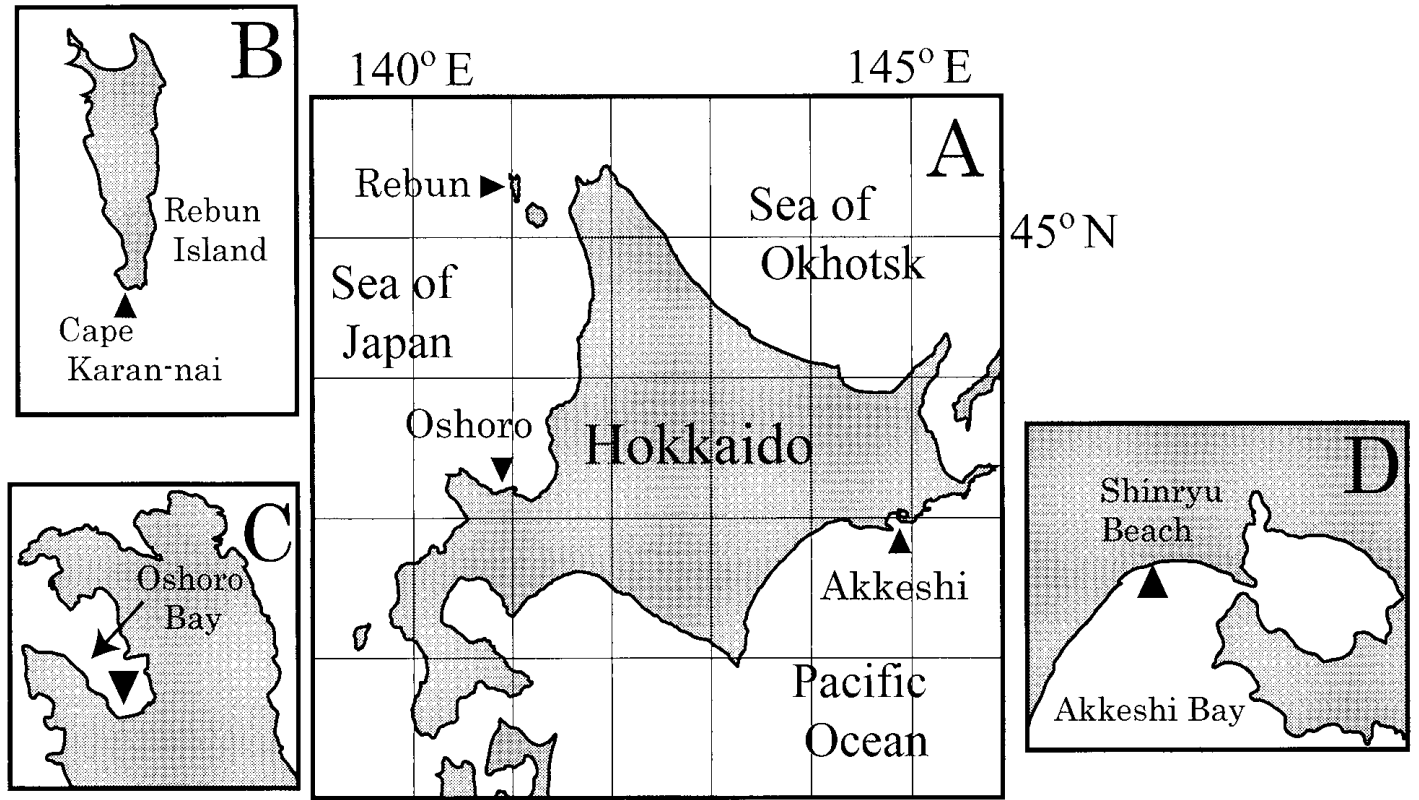

Fig. 1. Sampling points (triangles). A, Hokkaido; B, Rebun Island; C, Oshoro Bay; D, Akkeshi Bay.

\section{Material and Methods}

Sediment samples were taken from the surface layer $(<5 \mathrm{~cm}$ in depth) of intertidal zones at three localities around Hokkaido, Japan, viz., Rebun Island, Oshoro Bay, and Akkeshi Bay (Fig. 1A-D). The sediment was washed first in fresh water, then in seawater at laboratories so that nematodes could be separated by using a sieve $(63 \mu \mathrm{m}$ mesh). Nematode specimens were fixed with $10 \%$ formalin in seawater, transferred into $10 \%$ glycerin in $30 \%$ ethanol, then put in a desiccator for $2-3$ weeks. After evaporation, nematodes were preserved in pure glycerin. Specimens were mounted on glass slides in pure glycerin supported by paraffin wax ring (Hooper 1986) and sealed with Canada balsam as permanent mount, observed with a differential interference contrast microscope, and drawn with the aid of a camera lucida. Additional specimens were dehydrated through a graded ethanol series, dried with a critical point dryer (Hitachi HCP-2), and Au-coated with a ion spatter (JEOL JFC-1100), then observed with a scanning electron microscope (SEM; Hitachi S-3000N). The specimens examined have been deposited in the Hokkaido University Museum, Sapporo, Japan, cataloged under the acromym "ZIHU".

\section{Taxonomy}

Epacanthion quadridiscus sp. nov.

(Figs 2, 3, Table 1)

Material examined. Holotype: male, ZIHU 3360. Allotype: female, ZIHU 3365. 
Paratypes: males, ZIHU 3361-3364, 3385, 3386 (3385 and 3386, Au-coated for SEM); females, ZIHU 3366-3369. All collected by D. Shimada on 17 October 2007 from intertidal coarse sand at Cape Karan-nai $\left(45^{\circ} 16.3^{\prime} \mathrm{N}, 141^{\circ} 01.3^{\prime} \mathrm{E}\right)$, Rebun Island, Hokkaido, Japan (Fig. 1B).

Etymology. The specific name quadridiscus is a noun in apposition derived from the Latin quattuor (four) and discus (disk), referring to the four disk-like
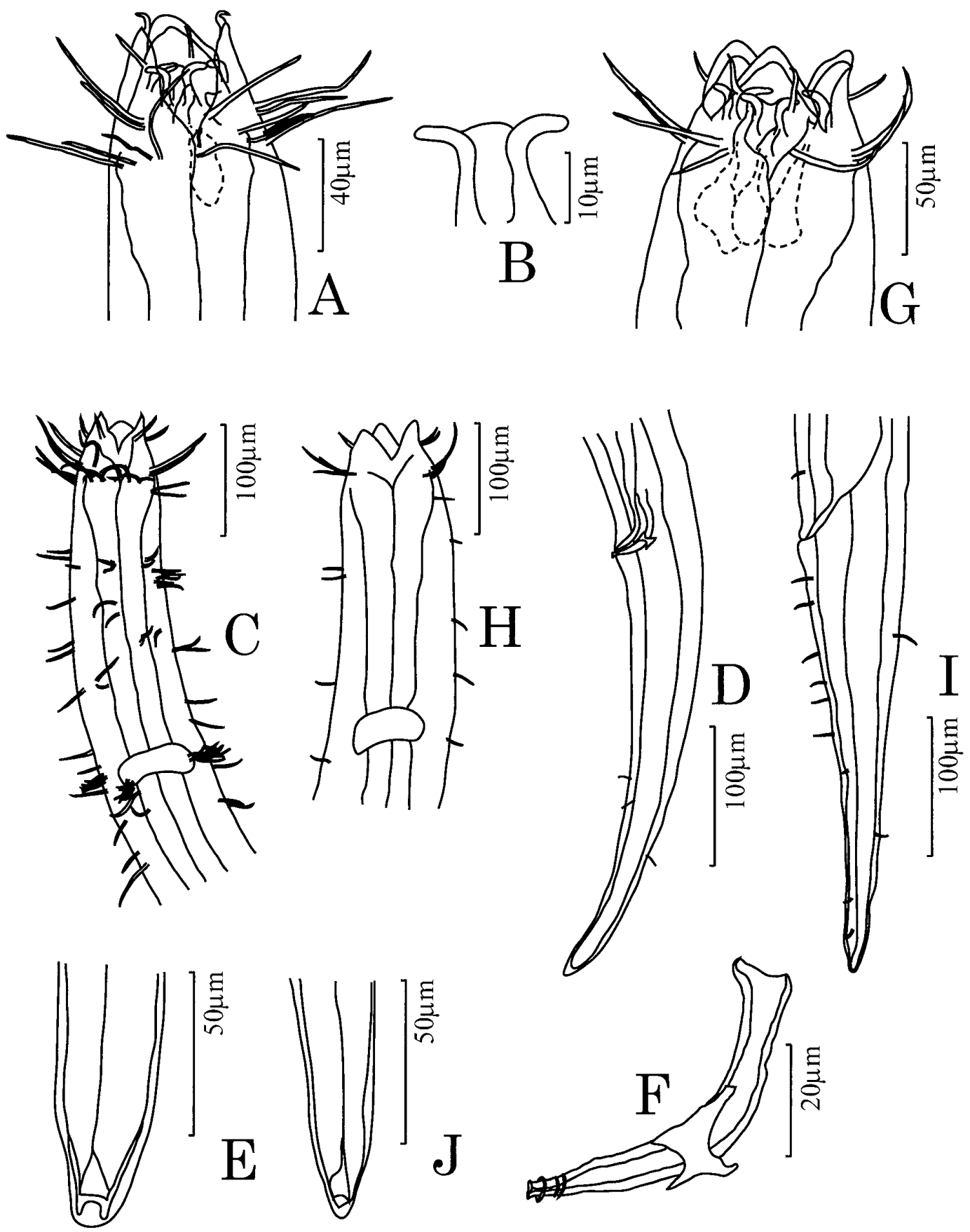

Fig. 2. Epacanthion quadridiscus sp. nov, males (A, B, D-F, holotype, ZIHU 3360; C, paratype, ZIHU 3361) and female (G-J, allotype, ZIHU 3365) in lateral views. A, G, Head; B, mandible; C, H, cervical region; D, I, tail; E, J, tail end; F, left spicule and gubernaculum. 

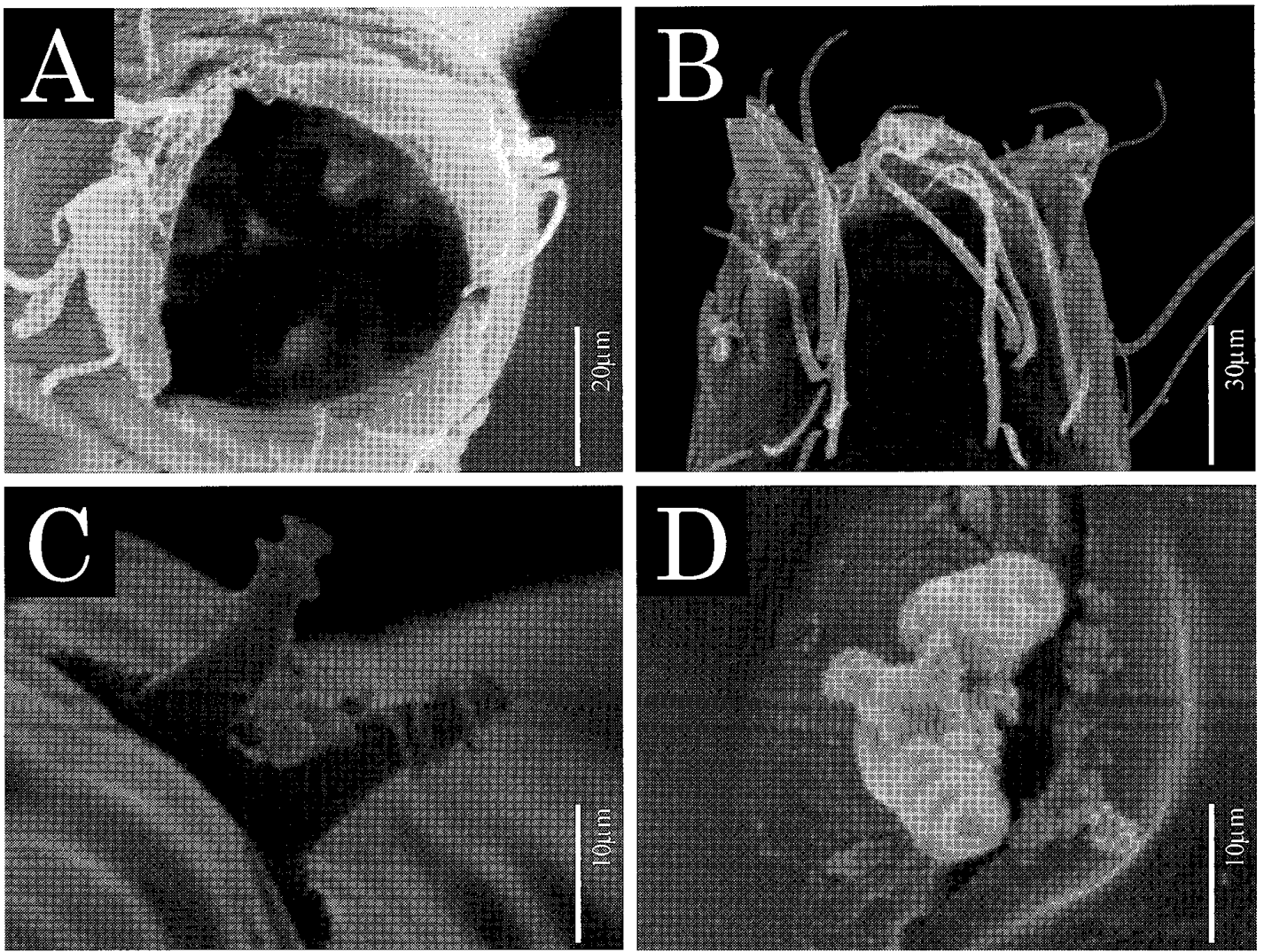

Fig. 3. Epacanthion quadridiscus sp. nov., SEM photographs of males (A, B, paratype, ZIHU 3385; C, D, paratype, ZIHU 3386). A, Head, frontal view; B, head, lateral view; C, spicules, frontal view; D, spicules, ventral view.

structures of the spicules.

Description. Body long, almost cylindrical, $4.4-5.9 \mathrm{~mm}$ in male and $5.0-5.6 \mathrm{~mm}$ in female. Maximum diameter $93-100 \mu \mathrm{m}$ in male and $103-115 \mu \mathrm{m}$ in female. Cuticle smooth. Head (Figs 2A, G, 3A, B) slightly tapered. Three lips high, six labial setae long. Six long and four short cephalic setae in single circle at middle of cephalic capsule. Buccal cavity small, conical in shape, with three mandibles and three onchia. Mandibles (Fig. 2B) well developed, each consisting of two hooked rods and one central thin sheet. Bases of mandibles situated at level of cephalic setae, tops situated at level of labial setae. Onchia solid, each length equal to that of mandible. Amphids and excretory pore not observed. Oesophagus cylindrical, 1/5 of body length, expanded at anterior end. Three large glands situated just posterior to buccal cavity, respectively opening at tip of each onchium. Nerve ring situated at $1 / 4$ of oesophagus length. Tail long, sexually dimorphic.

Male. Twelve pairs of subcephalic setae arranged in single circle (Fig. 3B), situated just posterior to cephalic setae. Cervical setae densely arranged between posterior end of head and level of nerve ring, further posteriorly becoming suddenly sparser (Fig. 2C). Six bundles of cervical setae in single circle situated at level of nerve ring (Fig. 2C). Spicules (Fig. 2F) relatively short for this genus, 1.0-1.2 times as long as cloacal diameter on arc; proximal end expanded; distal portion with four disk-shaped structures, consisting of three transverse ridges sur- 
Table 1. Measurements (in $\mu \mathrm{m}$ ) of Epacanthion quadridiscus sp. nov.

\begin{tabular}{|c|c|c|c|c|}
\hline & \multicolumn{2}{|c|}{ Males } & \multicolumn{2}{|c|}{ Females } \\
\hline & $\begin{array}{l}\text { Holotype } \\
\text { ZIHU } 3360\end{array}$ & $\begin{array}{c}\text { Paratypes* } \\
\text { ZIHU 3361-3364 }\end{array}$ & $\begin{array}{l}\text { Allotype } \\
\text { ZIHU } 3365\end{array}$ & $\begin{array}{c}\text { Paratypes* } \\
\text { ZIHU 3366-3369 }\end{array}$ \\
\hline Body length & 5619 & $5206(4434-5947)$ & 5580 & $5218(5007-5596)$ \\
\hline Maximum diameter & 93 & $96(93-100)$ & 125 & $107(103-115)$ \\
\hline \multicolumn{5}{|c|}{ Distance from anterior end of body to } \\
\hline nerve ring & 258 & $250(219-274)$ & 280 & $266(242-277)$ \\
\hline posterior end of oesophagus & 1063 & $1034(934-1127)$ & 1198 & $1078(1066-1108)$ \\
\hline vulva & - & - & 3140 & $2892(2740-3104)$ \\
\hline cloaca (anus) & 5281 & $4886(4144-5603)$ & 5239 & $4896(4679-5274)$ \\
\hline \multicolumn{5}{|l|}{ Body diameter at level of } \\
\hline head (at cephalic setae) & 52 & $54(52-56)$ & 79 & $63(48-70)$ \\
\hline posterior end of oesophagus & 81 & $87(84-93)$ & 123 & $99(93-109)$ \\
\hline vulva & - & - & 123 & $106(103-113)$ \\
\hline cloaca (anus) & 61 & $62(58-64)$ & 83 & $72(64-81)$ \\
\hline Longest labial seta length & 18 & $18(16-21)$ & 18 & $20(18-23)$ \\
\hline Longest cephalic seta length & 41 & $48(45-52)$ & 57 & $52(42-58)$ \\
\hline Longest subcephalic seta length & 42 & $41(37-47)$ & - & - \\
\hline Longest cervical seta length & 24 & $25(23-31)$ & 23 & $21(19-24)$ \\
\hline Tail length & 338 & $320(290-348)$ & 341 & $322(209-328)$ \\
\hline Tail length/cloacal diameter & 5.5 & $5.2(4.9-5.5)$ & 4.1 & $4.5(4.0-5.1)$ \\
\hline Spicule length on arc & 67 & $67(65-69)$ & - & - \\
\hline Spicule length on chord & 53 & $55(51-58)$ & - & - \\
\hline \multicolumn{5}{|l|}{ Spicule length on arc/ } \\
\hline cloacal diameter & 1.09 & $1.09(1.04-1.19)$ & - & - \\
\hline \multicolumn{5}{|l|}{ Spicule length on arc/ } \\
\hline Gubernaculum length & 30 & $34(31-36)$ & - & - \\
\hline $\begin{array}{l}\text { Gubernaculum length/ } \\
\text { spicule length on arc }\end{array}$ & 0.45 & $0.51(0.47-0.52)$ & - & - \\
\hline $\mathrm{V}(\%)$ & - & - & 56.3 & $55.4(54.6-56.8)$ \\
\hline $\mathrm{a}$ & 60.2 & $54.4(47.5-61.6)$ & 44.7 & $49.0(48.6-49.4)$ \\
\hline $\mathrm{b}$ & 5.3 & $5.0(4.7-5.4)$ & 4.7 & $4.8(4.6-5.2)$ \\
\hline $\mathrm{c}$ & 16.6 & $16.3(14.5-18.0)$ & 16.3 & $16.2(15.2-17.4)$ \\
\hline
\end{tabular}

* Mean (range).

Abbreviations: $\mathrm{V}$, position of vulva from anterior end of body as percentage of body length; a, body length/maximum diameter; $\mathrm{b}$, body length/distance from anterior end to posterior end of oesophagus; $\mathrm{c}$, body length/tail length.

rounding spicule and a round expansion of its distal end (Fig. 3C, D). Gubernaculum (Fig. 2F) large, H-shaped, with knob-like projection at dorsal proximal end. Precloacal supplement absent. Testis single, situated left of intestine. Tail (Fig. 2D, E) conical, slightly bent ventrally, 4.9-5.5 times as long as cloacal diameter, with sparse single short setae; tail end blunt, without any seta.

Female. Subcephalic setae and bundles of cervical setae absent (Fig. 2H). Single cervical setae present, fewer than in male. Reproductive system didelphic. Ovaries equal in shape and length, opposed, and not reflexed. Vulva situated at $55 \%$ of body length from anterior end. Tail (Fig. 2I, J) conical, not bent ventrally, 4.0-5.1 times as long as cloacal diameter, with sparse single short setae; tail end 
blunt, without any seta.

Diagnosis and Discussion. Epacanthion quadridiscus sp. nov. is characterized by a large body size $(4.4-5.9 \mathrm{~mm}$ long), a long tail (4.0-5.5 times cloacal diameter), $2 \times 12$ subcephalic setae, a single circle of six bundles of cervical setae at the level of the nerve ring in males, short spicules (1.0-1.2 times cloacal diameter on arc) with disk-shaped structures, a large $\mathrm{H}$-shaped gubernaculum, absence of a precloacal supplement, and unreflexed ovaries.

The genus Epacanthion currently consists of about 20 species, 11 of which possess short spicules as in $E$. quadridiscus sp. nov. Of these congeners, three species, E. enoploidiforme (Gerlach, 1953), E. gorgonocephalum Warwick, 1970, and E. georgei Inglis, 1971, are especially similar to E. quadridiscus in that they commonly possess a gubernaculum and lack a precloacal supplement (cf. Gerlach 1953; Warwick 1970; Inglis 1971). Epacanthion enoploidiforme and E. georgei differ from $E$. quadridiscus in their small gubernacula; E. enoploidiforme can also be distinguished from E. quadridiscus by the mandible shape, which is similar to that of species of the genus Enoploides Ssaweljev, 1912 (Gerlach 1953). Epacanthion gorgonocephalum differs from $E$. quadridiscus by the presence of $3 \times 12$ subcephalic setae and no bundles of cervical setae versus $2 \times 12$ subcephalic setae and bundles of cervical setae in the latter.

\section{Enoplolaimus longigubernaculum sp. nov.}

(Figs 4, 5, Table 2)

Material examined. Holotype: male, ZIHU 3351. Allotype: female, ZIHU 3356. Paratypes: males, ZIHU 3349, 3350, 3352-3354, 3387, 3388 (3387 and 3388, Au-coated for SEM); females, ZIHU 3355, 3357-3359. All collected by D. Shimada on 14 April 2008 from intertidal fine sand at Oshoro Bay $\left(43^{\circ} 12.3^{\prime} \mathrm{N}, 140^{\circ} 51.3^{\prime} \mathrm{E}\right)$, Hokkaido, Japan (Fig. 1C).

Etymology. The specific name longigubernaculum is a noun in apposition, referring to the fact that the gubernaculum of this species is the longest of any species in this genus.

Description. Body long, almost cylindrical, $4.4-4.9 \mathrm{~mm}$ in male and $5.2-5.9 \mathrm{~mm}$ in female. Maximum diameter $70-92 \mu \mathrm{m}$ in male and $101-132 \mu \mathrm{m}$ in female. Cuticle smooth. Head (Figs 4A, G, 5A, B) slightly tapered. Three lips high; six long labial setae situated at middle of cephalic capsule. Six long and four short cephalic setae in single circle at posterior end of cephalic capsule. Buccal cavity small, conical in shape, with three mandibles and three onchia. Mandibles (Fig. 4B) well developed, each consisting of two lateral rods and one curved bar. Bases of mandibles situated at level of cephalic setae and tips situated at level of labial setae. Onchia solid, shorter than mandibles. Amphids oval, just posterior to level of labial setae. Excretory pore not observed. Oesophagus cylindrical, $1 / 5$ of body length, expanded at anterior end. Three glands situated just posterior to buccal cavity, respectively opening at tip of each onchium. Nerve ring situated at $20-25 \%$ of oesophagus length. Tail long, sexually dimorphic.

Male. Subcephalic setae arranged in eight bundles (each bundle with four setae) in single circle situated just posterior to cephalic setae. Single cervical setae 

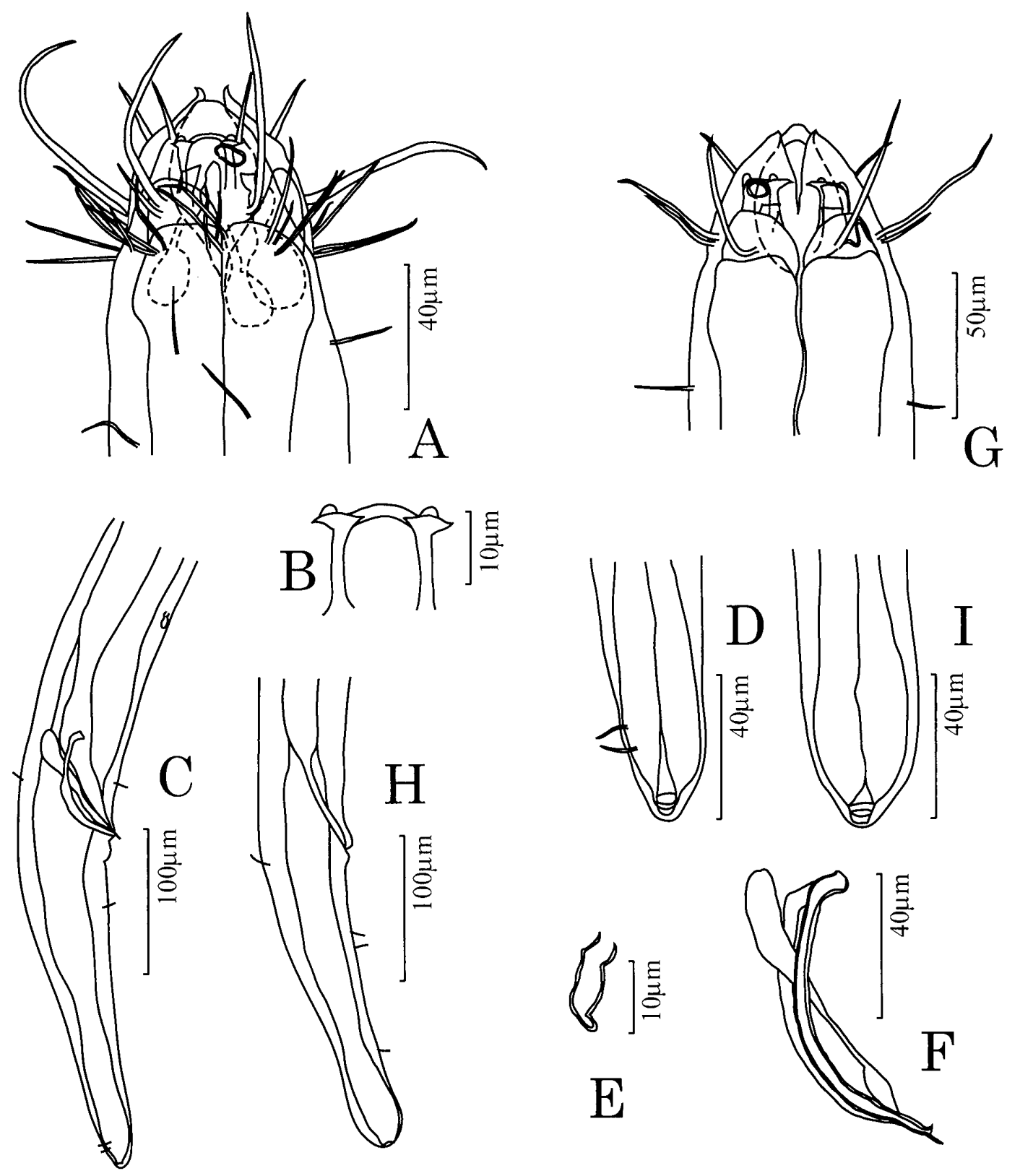

Fig. 4. Enoplolaimus longigubernaculum sp. nov., male (A-F, holotype, ZIHU 3351) and female (G-I, allotype, ZIHU 3356) in lateral views. A, G, Head; B, mandible; C, H, tail; D, I, tail end; E, precloacal supplement; F, spicules and gubernaculum.

densely arranged between posterior end of head and level of nerve ring, then becoming suddenly sparser. Spicules (Fig. 4F) of average length for this genus, 1.3-1.6 times cloacal diameter on arc, proximal end bent strongly like a handle, distal end slightly expanded. Gubernaculum (Fig. 4F) long, almost equal to spicules, straight, and without any accessory structure. Precloacal supplement (Fig. 4E) small, 11-13 $\mu \mathrm{m}$ long, situated at 2.0-2.6 times cloacal diameter anterior to cloaca. Testis single, situated left of intestine. Tail (Fig. 4C, D) conico-cylindrical, slightly bent ventrally, 3.1-4.0 times as long as cloacal diameter, with sparse single short setae; 

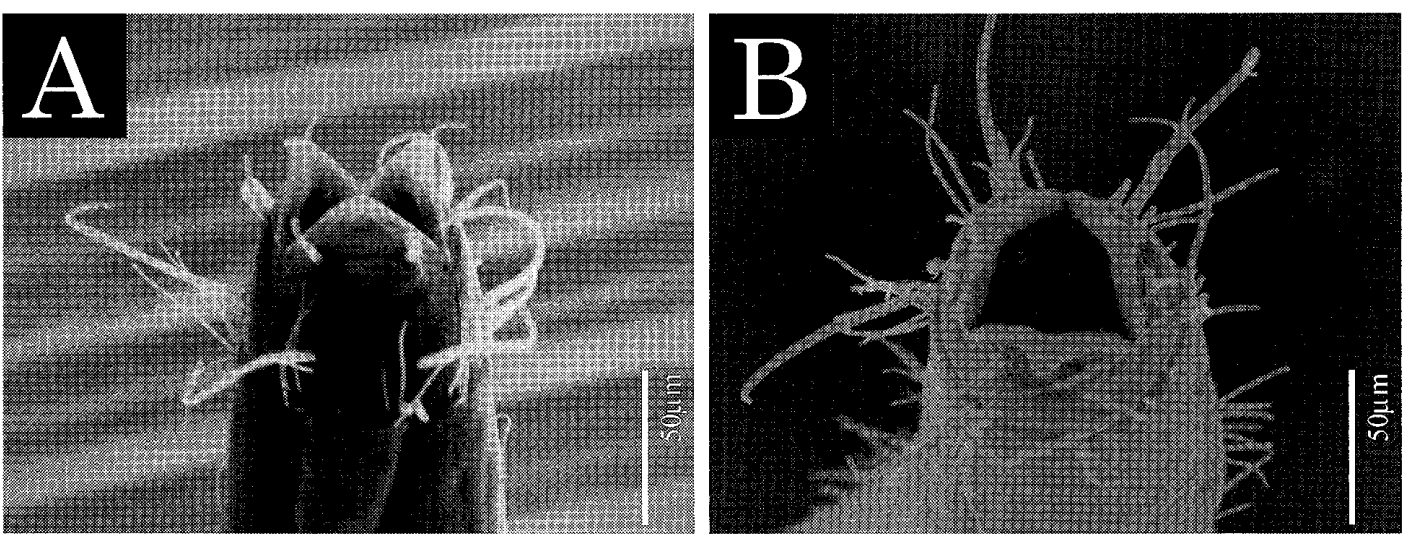

Fig 5. Enoplolaimus longigubernaculum sp. nov., SEM photographs of males (A, paratype, ZIHU 3387; B, paratype, ZIHU 3388). A, Head, lateral view; B, head, frontal view.

tail end blunt and expanded, with two pairs of short setae situated dorsally.

Female. Subcephalic setae absent. Single cervical setae present, fewer than in male. Reproductive system didelphic. Ovaries equal in shape and length, opposed, and not reflexed. Vulva situated at $60 \%$ of body length from anterior end. Tail (Fig. $4 \mathrm{H}, \mathrm{I})$ conico-cylindrical, not bent ventrally, 2.8-3.4 times as long as cloacal diameter, with sparse single short setae; tail end blunt and expanded, without any seta.

Diagnosis and Discussion. Enoplolaimus longigubernaculum sp. nov. is characterized by a large body size (4.4-5.9 $\mathrm{mm}$ long), 32 subcephalic setae (in eight bundles, each comprising four setae), curved spicules with a bent proximal end, and a long, straight gubernaculum (almost equal in length to spicules).

The genus Enoplolaimus includes ten species with curved (not straight) spicules and a straight gubernaculum as in E. longigubernaculum. However, $E$. longigubernaculum differs from all of them in the extremely long gubernaculum (length almost equal to spicule length vs almost equal to or shorter than 0.5 times spicule length in the other species).

Oncholaimus secundicollis sp. nov.

(Figs 6, 7, Table 3)

Material examined. Holotype: male, ZIHU 3370. Allotype: female, ZIHU 3378. Paratypes: males, ZIHU 3371-3377, 3389 (3389, Au-coated for SEM); females, ZIHU 3379-3384. All collected by D. Shimada on 3 July 2007 from intertidal fine sand containing hydrogen sulfide at Shinryu Beach $\left(43^{\circ} 01.1^{\prime} \mathrm{N}, 144^{\circ} 50.4^{\prime} \mathrm{E}\right)$, Akkeshi Bay, Hokkaido, Japan (Fig. 1D).

Etymology. The specific name secundicollis is a noun in apposition derived from the Latin secundus (following) and collis (hill). It refers to the presence of a postcloacal papilla following behind the precloacal papilla.

Description. Body long, almost cylindrical, $3.0-3.5 \mathrm{~mm}$ in male and $3.4-4.0 \mathrm{~mm}$ in female. Maximum diameter $70-79 \mu \mathrm{m}$ in male and $83-104 \mu \mathrm{m}$ in female. Cuticle smooth. Head (Figs 6A, 7A, B) rounded with six lips, slightly constricted just posterior to cephalic setae. Labial sensory organs six, papilliform. Ten $(6+4)$ short 
Table 2. Measurements (in $\mu \mathrm{m}$ ) of Enoplolaimus longigubernaculum sp. nov.

\begin{tabular}{|c|c|c|c|c|}
\hline & \multicolumn{2}{|c|}{ Males } & \multicolumn{2}{|c|}{ Females } \\
\hline & $\begin{array}{l}\text { Holotype } \\
\text { ZIHU } \\
3351\end{array}$ & $\begin{array}{c}\text { Paratypes* } \\
\text { ZIHU 3349-3350, } \\
\quad 3352-3354\end{array}$ & $\begin{array}{l}\text { Allotype } \\
\text { ZIHU } \\
3356\end{array}$ & $\begin{array}{c}\text { Paratypes* } \\
\text { ZIHU 3355, } \\
3357-3359\end{array}$ \\
\hline Body length & 5150 & $4692(4405-4910)$ & 5449 & $5580(5151-5890)$ \\
\hline Maximum diameter & 85 & 81. (70-92) & 96 & $116(101-132)$ \\
\hline \multicolumn{5}{|c|}{$\begin{array}{l}\text { Distance from anterior end of body to } \\
\text { posterior end of cephalic }\end{array}$} \\
\hline capsule & 35 & $36(32-39)$ & 41 & $40(38-44)$ \\
\hline nerve ring & 205 & $233(194-283)$ & 234 & $243(218-275)$ \\
\hline posterior end of oesophagus & 968 & $934(902-989)$ & 1055 & $1046(1012-1095)$ \\
\hline vulva & - & - & 3340 & $3383(3158-3615)$ \\
\hline cloaca (anus) & 4925 & $4479(4198-4698)$ & 5266 & $5323(4896-5612)$ \\
\hline \multicolumn{5}{|l|}{ Body diameter at level of } \\
\hline head (at cephalic setae) & 46 & $44(39-50)$ & 57 & $55(50-59)$ \\
\hline posterior end of oesophagus & 72 & $76(66-85)$ & 84 & $102(92-114)$ \\
\hline vulva & - & - & 90 & $115(99-132)$ \\
\hline cloaca (anus) & 65 & $61(52-69)$ & 67 & $81(75-85)$ \\
\hline Longest labial seta length & 19 & $16(13-18)$ & 18 & $17(15-18)$ \\
\hline Longest cephalic seta length & 52 & $53(48-56)$ & 54 & $53(51-56)$ \\
\hline Longest subcephalic seta length & 26 & $24(22-27)$ & - & - \\
\hline Longest cervical seta length & 17 & $16(22-27)$ & 16 & $15(22-27)$ \\
\hline Tail length & 225 & $213(207-224)$ & 183 & $257(234-278)$ \\
\hline Tail length/cloacal diameter & 3.5 & $3.5(3.1-4.0)$ & 2.7 & $3.2(2.8-3.4)$ \\
\hline Spicule length on arc & 86 & $88(80-94)$ & - & - \\
\hline Spicule length on chord & 69 & $68(58-71)$ & - & - \\
\hline $\begin{array}{l}\text { Spicule length on arc/ } \\
\text { cloacal diameter }\end{array}$ & 1.32 & $1.45(1.28-1.55)$ & - & - \\
\hline $\begin{array}{l}\text { Spicule length on arc/ } \\
\text { tail length }\end{array}$ & 0.38 & $0.41(0.39-0.45)$ & - & - \\
\hline Gubernaculum length & 89 & $76(71-89)$ & - & - \\
\hline $\begin{array}{l}\text { Gubernaculum length/ } \\
\text { spicule length on arc }\end{array}$ & 0.97 & $1.16(0.99-1.25)$ & - & - \\
\hline Precloacal supplement length & 11 & $12(11-13)$ & - & - \\
\hline $\begin{array}{l}\text { Distance between cloaca } \\
\text { and supplement }\end{array}$ & 130 & $137(132-139)$ & - & - \\
\hline $\mathrm{V}(\%)$ & - & - & 61.3 & $60.6(59.7-61.4)$ \\
\hline a & 60.6 & $58.6(47.9-65.5)$ & 56.8 & $48.4(43.8-51.0)$ \\
\hline $\mathrm{b}$ & 5.3 & $5.0(4.5-5.4)$ & 5.2 & $5.3(5.1-5.7)$ \\
\hline$c$ & 22.9 & $22.0(21.3-23.2)$ & 29.8 & $21.8(20.2-24.7)$ \\
\hline
\end{tabular}

* Mean (range).

Abbreviations: V, position of vulva from anterior end of body as percentage of body length; a, body length/maximum diameter; $b$, body length/distance from anterior end to posterior end of oesophagus; $c$, body length/tail length.

cephalic setae in single circle. Buccal cavity large, cylindrical in shape, with thick cuticular wall and three teeth. Left subventral tooth 1.5 times as long as right subventral or dorsal teeth, tip situated at level of cephalic setae. Amphids pocket-like (Fig. 7B), situated just posterior to tips of right subventral and dorsal teeth. Oesophagus cylindrical, $1 / 7-1 / 8$ of body length. Nerve ring situated at $45-50 \%$ of 

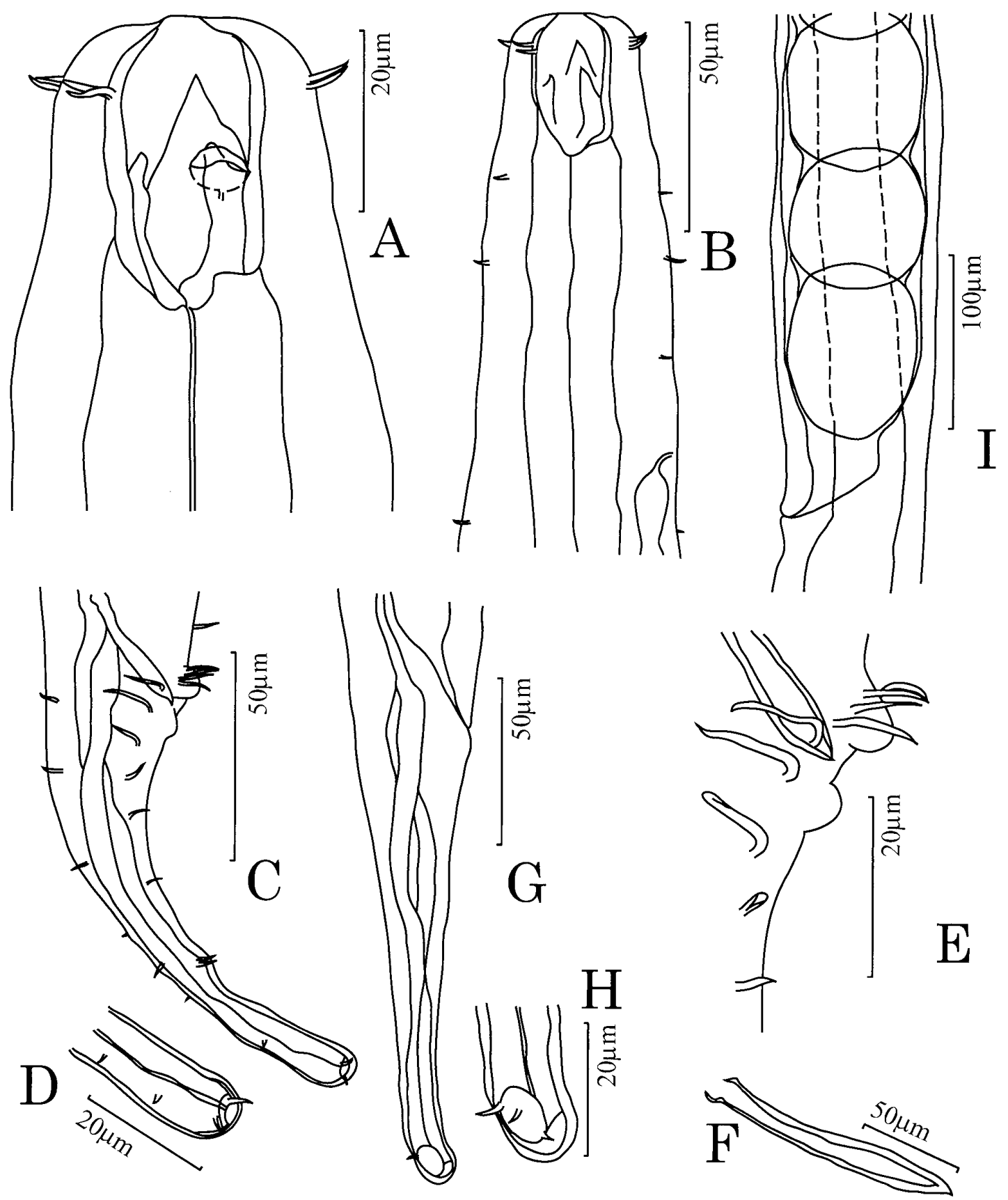

Fig. 6. Oncholaimus secundicollis sp. nov., male (A-F, holotype, ZIHU 3370) and female (G-I, allotype, ZIHU 3378) in lateral views. A, Head; B, cervical region; C, G, tail; D, H, tail end; E, precloacal and postcloacal papillae with nine cloacal setae; F, right spicule; I, vulva and eggs in uterus.

oesophagus length. Excretory pore situated at 2.4-3.5 times buccal cavity length from anterior end of body. Tail long, sexually dimorphic (Fig. 6B, C).

Male. Spicules (Fig. 6D) of average length for this genus, 0.9-1.2 times cloacal diameter on arc. Gubernaculum absent. Conspicuous fleshy precloacal papilla present just anterior to cloaca, and smaller postcloacal papilla just posterior to 

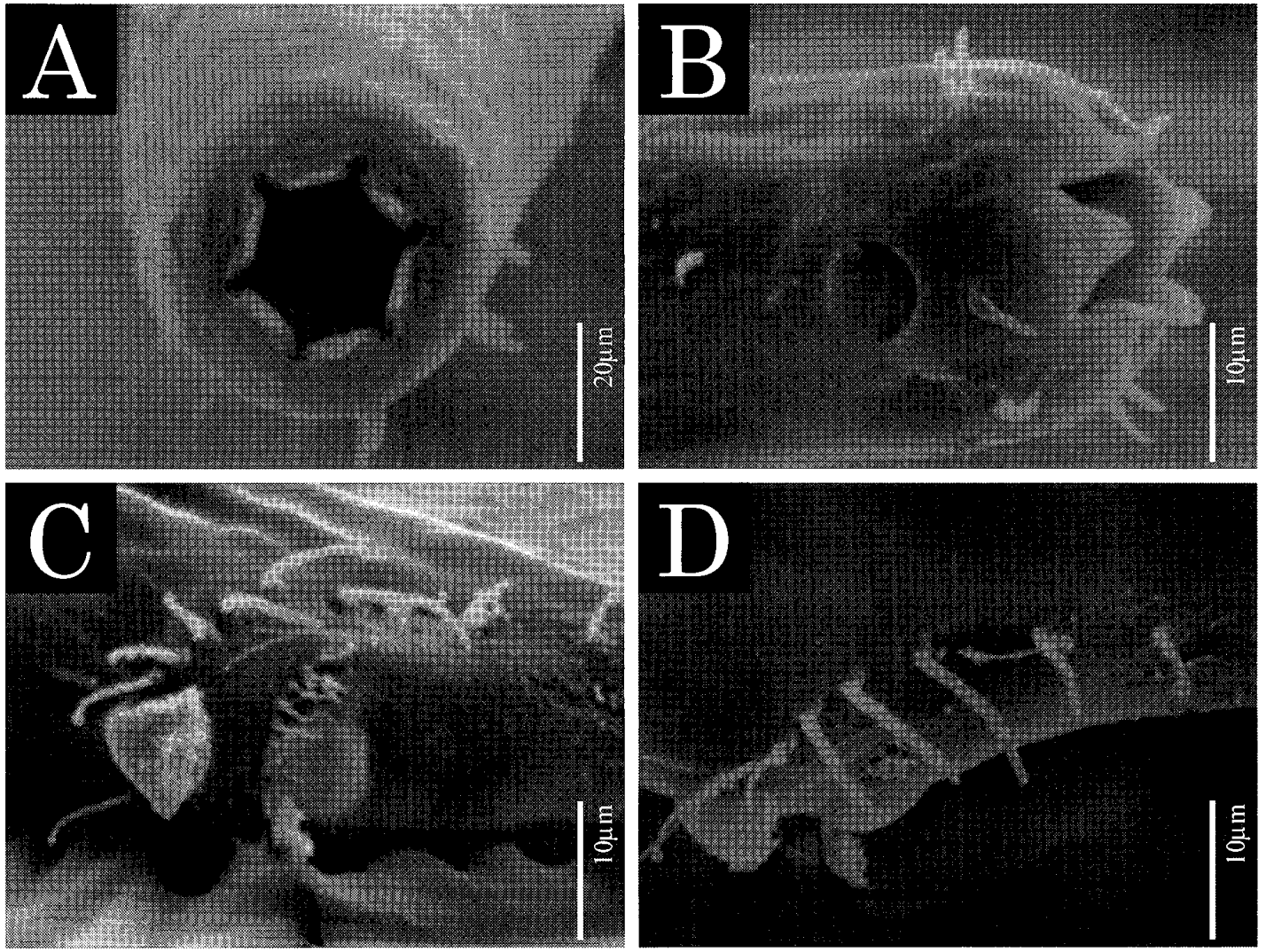

Fig. 7. Oncholaimus secundicollis sp. nov., SEM photographs of male (A-D, paratype, ZIHU 3389). A, Head, frontal view; B, head, lateral view; C, cloacal region, ventral view; D, cloacal region, lateral view.

cloaca (Fig. 7C, D). Nine pairs of long, stout cloacal setae situated from beside precloacal papilla to behind level of postcloacal papilla (Fig. 7C, D). Cloaca transversely slit-shaped, with about ten setae on anterior edge (Fig. 7C, D). Testes two, anterior one situated left of intestine, posterior one right of intestine. Tail (Fig. 6B) conico-cylindrical, anterior $2 / 3$ conical and posterior $1 / 3$ cylindrical, gradually bent ventrally, 2.7-3.2 times as long as cloacal diameter; tail end blunt, with two pairs of short setae. One ventral papilla with two pairs of short setae situated at $60-70 \%$ of tail length.

Female. Reproductive system monodelphic. Only anterior ovary present, not reflexed. Two or more (2-20 in observed specimens) large eggs in uterus. Vulva situated at $70 \%$ of body length. Demanian system not clear but present, with terminal duct opening situated at 1.0-1.5 times tail length anterior to anus. No papilla or setae found in anal region. Tail (Fig. 6C) conico-cylindrical, longer than that of male, 3.6-4.5 times cloacal diameter; tail end blunt, with two pairs of short setae.

Diagnosis and Discussion. Oncholaimus secundicollis sp. nov. is characterized by the presence of both a precloacal and a postcloacal papilla, as well as a long conico-cylindrical tail, longer in the female than in the male, with a ventral papilla, nine pairs of long and stout cloacal setae in the male, and a Demanian system in the female.

Although the genus Oncholaimus is a large group, containing more than 80 
Table 3. Measurements (in $\mu \mathrm{m}$ ) of Oncholaimus secundicollis sp. nov.

\begin{tabular}{|c|c|c|c|c|}
\hline & \multicolumn{2}{|c|}{ Males } & \multicolumn{2}{|c|}{ Females } \\
\hline & $\begin{array}{l}\text { Holotype } \\
\text { ZIHU } 3370\end{array}$ & $\begin{array}{c}\text { Paratypes* } \\
\text { ZIHU 3371-3377 }\end{array}$ & $\begin{array}{l}\text { Allotype } \\
\text { ZIHU } 3378\end{array}$ & $\begin{array}{c}\text { Paratypes* } \\
\text { ZIHU 3379-3384 }\end{array}$ \\
\hline Body length & 3274 & $3197(2987-3470)$ & 3713 & $3593(3383-3998)$ \\
\hline Maximum diameter & 70 & $73(70-79)$ & 91 & $95(83-104)$ \\
\hline \multicolumn{5}{|c|}{ Distance from anterior end of body to } \\
\hline amphid & 15 & $13(11-14)$ & 14 & $12(10-13)$ \\
\hline base of buccal cavity & 35 & $32(31-35)$ & 36 & $35(33-36)$ \\
\hline excretory pore & 103 & $104(87-110)$ & 94 & $95(85-111)$ \\
\hline nerve ring & 217 & $221(211-238)$ & 230 & $225(211-245)$ \\
\hline posterior end of oesophagus & 470 & $460(434-497)$ & 489 & $483(467-518)$ \\
\hline vulva & - & - & 2615 & $2534(2310-2845)$ \\
\hline cloaca (anus) & 3166 & $3103(2897-3379)$ & 3577 & $3466(3260-3852)$ \\
\hline demanian system opening & - & - & 3383 & $3308(3110-3676)$ \\
\hline \multicolumn{5}{|l|}{ Body diameter at leve of } \\
\hline head (at cephalic setae) & 29 & $28(26-32)$ & 29 & $30(28-31)$ \\
\hline posterior end of oesophagus & 63 & $68(65-76)$ & 78 & $76(73-81)$ \\
\hline vulva & - & - & 83 & $83(73-92)$ \\
\hline cloaca (anus) & 32 & $31(28-34)$ & 31 & $32(29-34)$ \\
\hline Longest cephalic seta length & 7 & $6(5-7)$ & 7 & $6(5-7)$ \\
\hline Amphid width & 7 & $8(7-10)$ & 7 & $8(7-9)$ \\
\hline Amphid width/head diameter & 0.25 & $0.28(0.22-0.36)$ & 0.25 & $0.26(0.23-0.31)$ \\
\hline Buccal cavity width & 14 & $16(14-22)$ & 17 & $17(15-19)$ \\
\hline Longest cloacal seta length & 10 & $11(9-13)$ & - & - \\
\hline Tail length & 109 & $94(89-104)$ & 136 & $127(117-146)$ \\
\hline Tail length/cloacal diameter & 3.4 & $3.0(2.7-3.2)$ & 4.4 & $4.0(3.6-4.5)$ \\
\hline Spicule length on arc & 29 & $32(31-32)$ & - & - \\
\hline Spicule length on chord & 28 & $31(30-31)$ & - & - \\
\hline \multicolumn{5}{|l|}{ Spicule length on arc/ } \\
\hline cloacal diameter & 0.90 & $1.02(0.91-1.16)$ & - & - \\
\hline Spicule length on arc/tail length & 0.27 & $0.34(0.31-0.36)$ & - & - \\
\hline $\mathrm{V}(\%)$ & - & - & 70.4 & $70.5(68.3-71.3)$ \\
\hline a & 47.0 & $44.1(40.7-49.8)$ & 40.9 & $38.3(33.5-41.7)$ \\
\hline $\mathrm{b}$ & 7.0 & $7.0(6.7-7.2)$ & 7.6 & $7.4(7.2-7.7)$ \\
\hline $\mathrm{c}$ & 30.2 & $33.6(30.2-38.3)$ & 27.3 & $28.2(26.8-30.3)$ \\
\hline
\end{tabular}

* Mean (range).

Abbreviations: V, position of vulva from anterior end of body as percentage of body length; a, body length/maximum diameter; $b$, body length/distance from anterior end to posterior end of oesophagus; $c$, body length/tail length.

species, only five species, that is, O. appendiculatus (Cobb, 1930), O. campylocercoides De Coninck and Stekhoven, 1933, O. domesticus (Chitwood and Chitwood, 1938), O. qingdaoensis Zhang and Platt, 1983, and O. sinensis Zhang and Platt, 1983, are reported to have a precloacal papilla and a tail papilla in the male. Oncholaimus secundicollis sp. nov. is clearly distinguished from all of them in having a postcloacal papilla in addition to a precloacal and a tail papilla in the male. However, we assume the postcloacal papilla might be overlooked in the five congeners owing to small size. Even so, $O$. campylocercoides and $O$. domesticus differ from O. secundicollis by the presence of two tail papillae (cf. Wieser and Hopper 1967; 
Platt and Warwick 1983). Oncholaimus appendiculatus differs from this new species in the spicule length (about 2.5 times the cloacal diameter in O. appendiculatus vs 0.9-1.1 times in O. secundicollis) (cf. Wieser and Hopper 1967), and O. qingdaoensis differs in the conical tail shape (cf. Zhang and Platt 1983). Oncholaimus sinensis also differs from the new species by the presence of the 11 pairs of cloacal setae (nine pairs in O. secundicollis) (cf. Zhang and Platt 1983).

\section{Acknowledgements}

We wish to express our thanks to Dr K. Kito (Sapporo Medical University) for his critical reading of the manuscript and valuable comments. We also thank all the staff of the Oshoro Marine Station and the Akkeshi Marine Station of Hokkaido University for offering facilities for our study.

\section{References}

Allen, M. W. and Noffsinger, E. M. 1978. A revision of the marine nematodes of the superfamily Draconematoidea Filipjev, 1918 (Nematoda: Draconematina). University of California Publications in Zoology 109: 1-133.

Allgén, C. 1951. Papers from Dr. Th. Mortensen's Pacific Expedition 1914-1916. 76. Pacific freeliving marine nematodes. Videnskabelige Meddelelser fra Dansk Naturhistorisk Forening i København 113: 263-411.

Aryuthaka, C. 1989a. Some free-living marine nematodes from a seagrass (Zostera marina) bed and the adjacent intertidal zone, Amakusa, South Japan. Publications from the Amakusa Biological Laboratory 10: 1-15.

Aryuthaka, C. 1989b. Two new species of the genus Rhynchonema (Nematoda, Xyalidae) from Amakusa, South Japan. Hydrobiologia 171: 3-10.

Gerlach, S. A. 1953. Die Nematodenbesiedlung des Sandstandes und des Küstengrundwassers an der italienischen Küste. 1. Systematischer Teil. Archivio Zoologico Italiano 37: $517-640$.

Hooper, D. J. 1986. Handling, fixing, staining and mounting nematodes. Pp. 59-80. In: Southey, J. F. (Ed.) Laboratory Methods for Work with Plant and Soil Nematodes. Her Majesty's Stationery Office, London.

Inglis, W. G. 1971. Marine Enoplida (Nematoda) from Western Australia. Transactions of the Royal Society of South Australia 95: 65-78.

Kito, K. 1976. Studies on the free-living marine nematodes from Hokkaido. I. Journal of the Faculty of Science, Hokkaido University, Series 6, Zoology 20: 568-578.

Kito, K. 1977. Studies on the free-living marine nematodes from Hokkaido. II. Proceedings of the Japanese Society of Systematic Zoology 13: 17-23.

Kito, K. 1978a. Studies on the free-living marine nematodes from Hokkaido. III. Journal of the Faculty of Science, Hokkaido University, Series 6, Zoology 21: 248-261.

Kito, K. 1978b. Five species of marine nematodes of the genus Chromadora Bastian from Japan. Annotationes Zoologicae Japonenses 51: 164-178.

Kito, K. 1981. Studies on the free-living marine nematodes from Hokkaido. IV. Journal of the Faculty of Science, Hokkaido University, Series 6, Zoology 22: 250-278.

Kito, K. and Hope, W. D. 1999. Leptosomatides brevicaudatus sp. nov. and a redescription of 
Leptosomatides marinae Platonova, 1967 (Enoplida: Leptosomatidae). Journal of Nematology 31: 460-474.

Platt, H. M. and Warwick, R. M. 1983. Free-living Marine Nematodes. Part 1. British Enoplids. Synopses of the British Fauna (New Series) No. 28. Cambridge University Press, Cambridge, vii $+307 \mathrm{pp}$.

Steiner, G. and Hoeppli, R. 1926. Studies on the exoskeleton of some Japanese marine nemas. Archiv für Schiffs- und Tropen-Hygiene Pathologie und Therapie Exotischer Krankheiten 30: 547-576.

Warwick, R. M. 1970. Fourteen new species of free-living marine nematodes from the Exe Estuary. Bulletin of the British Museum, Natural History, Zoology 19: 137-177.

Wieser, W. 1955. A collection of marine nematodes from Japan. Publications of the Seto Marine Biological Laboratory 4: 159-181.

Wieser, W. and Hopper, B. 1967. Marine nematodes of the east coast of North America. I. Florida. Bulletin of the Museum of Comparative Zoology at Harvard University 135: $239-244$.

Yoshimura, K. 1980a. Free-living marine nematodes from Kii Peninsula. I. Publications of the Seto Marine Biological Laboratory 25: 39-49.

Yoshimura, K. 1980b. Five species of the genus Eurystomina Filipjev, 1921. Publications of the Seto Marine Biological Laboratory 25: 373-387.

Yoshimura, K. 1982. Free-living marine nematodes from Kii Peninsula. II. Publications of the Seto Marine Biological Laboratory 27: 133-142.

Zhang, Z. N. and Platt, H. M. 1983. New species of marine nematodes from Qingdao, China. Bulletin of the British Museum, Natural History, Zoology 45: 253-261. 